\title{
Melihat Kondisi Kesetimbangan Ekologi Terumbu Karang di Pulau Sempu, Malang Menggunakan Pendekatan Luasan Koloni Karang Keras (Scleractinia)
}

\author{
Oktiyas Muzaky Luthfi ${ }^{1}$, Vindi Lovina Rahmadita ${ }^{1}$, dan Daduk Setyohadi ${ }^{2}$ \\ 1Marine Science University of Brawijaya Malang, Jl. Veteran Malang; e-mail: omuzakyl@ub.ac.id \\ ${ }^{2}$ Fisheries Resources Utilization University of Brawijaya Malang, Jl. Veteran Malang
}

\begin{abstract}
ABSTRAK
Pulau Sempu adalah satu-satunya cagar alam yang berada di Kabupaten Malang yang memiliki terumbu karang dengan luasan kurang dari 10 ha yang mampu bertahan dari banyaknya ancaman yang berpotensi merusaknya. Faktor lingkungan secara alamiah telah menyeleksi keanekaragaman diwilayah perairan P. Sempu, yakni hanya 9 life form karang keras yang berperan sebagai penyangga ekosistem terumbu karang di wilayah ini. Mengetahui distribusi ukuran koloni karang sama pentingnya mengetahui umur koloni karang keras untuk melihat kondisi ekosistem terumbu karang pada suatu perairan. Klas frekuensi koloni karang keras akan memberikan informasi mengenai kemampuan kompetisi, masa pubersitas dan tentu kemampuan regenerasi. Pengambilan data luasan karang dilakukan di 4 stasium (Watu Mejo 1, Watu Mejo 2, Teluk Semut 1 dan Teluk Semut 2) menggunakan kuadrat transek $1 \times 1 \mathrm{~m}$ sepanjang $50 \mathrm{~m}$ pada kedalaman $5 \mathrm{~m}$. Berdasarkan penelitian didapatkan luasan total tertinggi pada Acropora Branching (ACB) adalah 145.811,67 $\mathrm{cm}^{2}$ dan terenda pada karang jamur (CMR) 414,35 $\mathrm{cm}^{2}$. Life form karang dapat dijadikan rujukan awal menilai kesehatan ekosistem terumbu karang. Dominan karang dengan life form massive dapat diartikan kawasan tersebut memiliki kondisi lingkungan yang penuh tekanan semisal sedimentasi tinggi, arus kuat maupun sering terekspos udara. Ukuran karang di P. Sempu rerata menunjukkan $>5 \mathrm{~cm}^{2}$ yang berarti sudah dewasa dan mampu melakukan reproduksi, sedangkan rekruitmen sangat rendah dengan indikasi sedikitnya jumlah luasan karang kurang dari $4 \mathrm{~cm}^{2}$.
\end{abstract}

Kata kunci: cagar alam, bentuk pertumbuhan, reproduksi, konservasi, karang keras

\begin{abstract}
The abundance of coral reef in Sempu Island nature reserve was under 10 ha, in which they were a winner from environment and human threats. The environment has big role to select scleractinian coral in this area that resulted 9 coral life form as the main foundation of coral reef in Sempu nature reserve area. Knowing the coral size distribution as important to know of coral age in term determining the health of coral reef ecosystem. Class frequency of colony size gave the key information of coral competition, puberty and regeneration ability. We choose 4 station (Watu Mejo 1, Watu Mejo 2, Teluk Semut 1 dan Teluk Semut 2) to take data. Data colony size was taken by $1 \mathrm{x} 1 \mathrm{~m}$ quadrat along $50 \mathrm{~m}$ in $5 \mathrm{~m}$ depth. The highest colony size was Acropora branching (ACB) about 145,811.67 $\mathrm{cm}^{2}$ and the lowest one was mushroom coral (CMR) about $414.35 \mathrm{~cm}^{2}$. Life form of coral can be early detection of coral reef health. Dominance of massive coral means the coral reef under the high sedimentation, strong current or exposed by air frequently. The coral colony size in Sempu nature reserve showed $>5 \mathrm{~cm}^{2}$ that indicate they were in maturity and have capability for reproduction but the coral recruitment was very low due to few number of coral has less than $4 \mathrm{~cm}^{2}$ in colony size.
\end{abstract}

Keywords: nature reserve, life form, reproduction, conservation, coral

Citation: Luthfi, O.M., Rahmadita, V.L., dan Setyohadi, D. (2018). Melihat Kondisi Kesetimbangan Ekologi Terumbu Karang di Pulau Sempu, Malang Menggunakan Pendekatan Luasan Koloni Karang Keras (Scleractinia). Jurnal Ilmu Lingkungan, 16(1), 1-8, doi:10.14710/jil.16.1.1-8

\section{Pendahuluan}

Karang keras (scleractinian) merupakan salah satu organisme terpenting dalam ekosistem terumbu karang, kerena akan sebagai pembentuk struktur utama terumbu karang dan juga menyediakan substrat serta tempat tinggal bagi berbagai biota/ organisme laut (Pandolfi et al., 2003). Kerusakan terhadap karang keras dimungkinkan akan berdampak kepada menurunnya atau bahkan kemusnahan terhadap biota/ organisme yang tinggal dan berasosiasi dengan karang. Karang keras diperairan P. Sempu terkonsentrasi pada selat Sempu yakni membuat barisan karang tepi (fringing reef) dari timur hingga barat selat Sempu (Luthfi et al., 2016). Komposisi karang keras di P. Sempu adalah 
cerminan dari kondisi lingkungan dimana karang tersebut tinggal/ hidup, karang yang berada disebelah timur di dominasi oleh Acropora bercabang (ACB) yang menggambarkan kondisi arus yang lebih kencang dengan perairan relative jernih, sedangkan di sebelah barat didominasi oleh karang bercabang nonAcropora (CB) dan karang masiv (CM) yang menggambarkan kondisi perairan disekitarnya memiliki tekanan dari alam seperti sedimentasi dan kejernihan perairan yang rendah (Luthfi, et al., 2014). Berbagai ancaman terhadap terumbu karang di P. Sempu yang pernah tercatat yakni sedimentasi tinggi pada kurun 2006-2009 akibat proyek reklamasi perluasan pelabuhan pendaratan ikan Sendang Biru, pemutihan massal pada 2010 dan 2015, dan kegiatan pariwisata telah mengakibatkan tutupan karang hidup di wilayah ini berada stuck pada kisaran 37\% (rerata data 2009-2016).

Angka tutupan karang hidup tersebut dihitung menggunakan metode line intercept transect (LIT). LIT telah digunakan Loya dan Slobodkin (1971) yang menggunakan panjang transek $10 \mathrm{~m}$, kemudian Loya (1972) menggunakan transek garis $10 \mathrm{~m}$ dengan ulangan 84 kali juga untuk melihat kelimpahan karang di Laut Merah. Dua decade berikutnya English et al (1994) menggunakan LIT sepanjang $100 \mathrm{~m}$ untuk memberikan gambaran kondisi ekosistem terumbu karang, dan banyak digunakan hingga saat ini. Kelemahan metode ini adalah hanya mengambil sampel terumbu karang yang persis dibawah transek sehingga, kurang mencerminkan kondisi ekosistem terumbu karang secara menyeluruh. Ada pendekaan lain untuk menilai tutupan karang hidup pada suatu wilayah yaitu, transek kuadrat. Transek kuadrat secara jelas mengkuantifikasikan luasan karang keras pada suatu wilayah dengan hasil lebih bagus dibandingkan dengan line transect, karena menggambarkan luasan sampel karang pada suatu wilayah. Transek kuadrat telah dipakai sejak tahun 1969 di Maladewa dengan ukuran 3x3 m (Stodart, 1969), kemudian Loya (1972) menggunakan transek yang sama untuk mengestimasi kondisi terumbu karang di kawasan reef flat Laut Merah serta Hughes (1989) menggunakan transek 0,5 x 0,5 m di Rio Bueno, Jamaika untuk melihat coral cover pasca terjadi taifun.

Kondisi terumbu karang selama ini dihitung menggunakan proporsional karang hidup dengan total substrat yang ditemukan dibawah transek (Loya, 1972; English et al., 1994; Williams et al., 2001; Bruno dan Selig, 2007). Luasan koloni karang keras selain dapat menunjukkan kualitas terumbu karang pada suatu wilayah dapat juga digunakan sebagai "alat" untuk melihat dinamika sebuah populasi, misalnya karang pada luasan tertentu akan dapat diklasifikasikan sebagai larva, juvenile atau dewasa (Hughes, 1989). Selain menjelaskan umur, mengetahui ukuran koloni karang akan dapat melihat populasi karang di suatu wilayah, apakah sedang mengalami kenaikan atau penurunan populasi (Bak dan Meesters, 1998). Nantinya dari data yang ada akan dapat diketahui seberapa besar pengaruh lingkungan terhadap masa depan terumbu karang di suatu wilayah. Tujuan dari penelitian ini adalah untuk mengetahui distribusi ukuran koloni karang diperaian P. Sempu.

\section{Metode Penelitian}

\subsection{Lokasi dan Waktu Penelitian}

Penelitian telah dilaksanakan pada Juli-Agustus 2014 di P. Sempu, Sendang Biru, Kabupaten Malang. Pengambilan data terumbu karang telah dilakukan pada empat titik stasiun yaitu : staiun 1 , Teluk Semut $1\left(08^{0} 26^{\prime} 20,8^{\prime \prime}\right.$ LS; $112^{0} 40^{\prime} 52,5^{\prime \prime}$ BT), stasiun 2, Teluk Semut $2\left(08^{0} 25^{\prime} 55,1^{\prime \prime} \mathrm{LS} ; 112^{0} 41^{\prime} 24,3^{\prime \prime} \mathrm{BT}\right)$, stasiun 3, Watu Mejo $1\left(08^{0} 25^{\prime} 44,6^{\prime \prime} \mathrm{LS} ; 112^{0} 41^{\prime} 50,4^{\prime \prime}\right.$ BT), dan stasiun 4, Watu Mejo $2 \quad\left(08^{0} 26^{\prime} 27,0^{\prime \prime} \quad\right.$ LS; $112^{0} 40^{\prime} 49,8^{\prime \prime B T)}$. Stasiun 1 dan 4 dipilih karena kondisi perairannya yang berbatasan langsung dengan Samudera Hindia yaitu berada pada ujung selat Sempu sebelah barat untuk Teluk Semut 1, dan sebelah timur untuk Watu Mejo 2. Sedangkan untuk stasiun 2 dan 3 yaitu Teluk Semut 2 dan Watu Mejo 1 dipilih karena lokasi tersebut berada pada wilayah tengah dari Selat Sempu. Lokasi tersebut dipilih dan diestimasikan bahwa pengambilan data di 4 stasiun telah mewakili data komunitas karang di P. Sempu secara keseluruhan.

\subsection{Pengambilan Data Tutupan dan Koloni Karang}

Karang keras di P. Sempu merupakan komunitas yang kecil, mereka membentuk fringing reef pada kedalaman tidak lebih dari $7 \mathrm{~m}$. Pengambilan data tutupan dan ukuran koloni karang dilakukan pada kedalaman antara 3-7 m, menggunakan SCUBA. Data diambil menggunakan transek kuadrat 1 x $1 \mathrm{~m}$ sepanjang $50 \mathrm{~m}$ yang diletakaan sejajar dengan garis pantai (English et al., 1994). Kemudian dilakukan perekaman menggunakan kamera bawah air Canon G 16 (Jepang) minimal sebanyak 5 kali foto disetiap transek, dengan rincian: 1 kali perekaman pada transek 1 x $1 \mathrm{~m}$, kemudian 4 kali perekaman pada subtransek 50 x $50 \mathrm{~cm}$. Data dari kamera selanjutnya di pindah ke computer untuk dilakukan editing warna, identifikasi hingga level genus dan penghitungan luasan karang yang berada didalam transek. Software yang digunakan untuk penghitungan luas adalah Image-J (NIH, Amerika) (Luthfi et al., 2014).

\subsection{Analisa data}

Pengukuran tutupan karang keras mengacu pada English et al., (1994) (rumus 1) sedangkan pengklasifikasian klas frekuensi pada karang menggunakan metoda dari Soong (1993) yakni mengurutkan dari kelas terkecil (0-4 $\left.\mathrm{cm}^{2}\right)$, terkecil ke 2 hingga kelas terbesar $\left(>4000 \mathrm{~cm}^{2}\right)$ (Gambar 2$)$.

$$
P=\frac{a}{A} 100 \%
$$


Dimana,

P : Persentase tutupan karang

a : Luas karang jenis tertentu

A : Total luas transek

\section{Hasil dan Pembahasan}

\subsection{Life form karang}

Life form karang yang ditemukan di seluruh stasiun di perairan Sendang Biru, Kabupaten Malang adalah sebanyak 9 jenis antara lain adalah Acropora branching (ACB) sebanyak 218 koloni dengan sebaran sebagai berikut: 36 koloni terdapat di stasiun Watu Mejo 1, 135 koloni terdapat di stasiun Watu Mejo 2, 36 koloni terdapat distasiun Teluk Semut 1, dan 11 koloni terdapat di stasiun Teluk Semut 2, Acropora tabulate (ACT) sebanyak 6 koloni dan hanya terdapat di stasiun Watu Mejo 1, coral branching (CB) sebanyak 405 koloni dengan sebaran sebagai berikut: 33 koloni terdapat di stasiun Watu Mejo 1, 1 koloni terdapat di stasiun Watu Mejo 2, 90 koloni terdapat stasiun Teluk Semut 1, dan 281 koloni terdapat di stasiun Teluk Semut 2. Coral foliose (CF) sebanyak 209 koloni dengan sebaran sebagai berikut: 14 koloni terdapat di stasiun Watu Mejo 1, 52 koloni terdapat di stasiun Watu Mejo 2, 136 koloni terdapat di stasiun Teluk Semut 1, dan 7 koloni terdapat di stasiun Teluk Semut 2 , coral massive (CM) sebanyak 437 koloni dengan sebaran sebagai berikut: 45 koloni terdapat di stasiun Watu Mejo 1, 44 koloni terdapat di stasiun Watu Mejo 2, 23 koloni terdapat di stasiun Teluk Semut 1, dan 325 koloni terdapat di stasiun Teluk Semut 2, coral encrusting (CE) sebanyak 106 koloni dengan sebaran sebagai berikut: 15 koloni terdapat di stasiun Watu Mejo 1, 12 koloni terdapat di stasiun Watu Mejo 2, 1 koloni terdapat di stasiun Teluk Semut 1, dan 78 koloni terdapat di stasiun Teluk Semut 2, coral submassive (CS) sebanyak 90 koloni dengan sebaran sebagai berikut: 51 koloni terdapat di stasiun Watu Mejo 1, 34 koloni terdapat di stasiun Teluk Semut 1, dan 5 koloni terdapat di stasiun Teluk Semut 2, coral mushroom (CMR) sebanyak 7 koloni dengan sebaran sebagai berikut: 1 koloni terdapat di stasiun Watu Mejo 2, 5 koloni terdapat di stasiun Teluk Semut 1, dan 1 koloni terdapat di stasiun Teluk Semut 2, serta coral meliopora (ME) sebanyak 38 koloni dengan sebaran sebagai berikut: 37 koloni terdapat di stasiun Watu Mejo 1 dan 1 koloni terdapat di stasiun Teluk Semut 1.

Bentuk pertumbuhan (life form) dapat memberikan informasi tersembunyi (hidden information) terhadap kondisi lingkungan perairan suatu wilayah, Edinger dan Risk (2000) memberikan tiga klasifikasi terhadap hubungan bentuk pertumbuhan karang dengan lingkungan perairan sekitarnya yakni: pertama ruderals (r) yaitu karangkarang yang mudah beradaptasi dengan lingkungan atau cepat melakukan adaptasi terhadap kerusakan, contohnya adalah karang Acropora, dimana hampir semua Acropora memiliki pertumbuhan cepat namun gampang sekali patah. Kedua competitor (K), karang non Acropora berbentuk foliose dan branching yang mendominasi suatu perairan dan memiliki pertumbuhan cepat walaupun kurang cepat dibandingkan dengan Acropora. Ketiga adalah karang yang memiliki kemampuan menangkal stress (stress tolerator) (S) yakni semua karang massive dan submassive yang memiliki kemampuan bertahan terhadap sedimentasi dan eutrifikasi perairan.

Melihat tabel 2 karang Acropora baik tabulate (meja) maupun branching (bercabang) banyak ditemukan pada station WM1(st. 3) dan WM2 (st. 4), memang kedua station tersebut terdapat pada mulut teluk sebelah timur yang memiliki arus deras (pengalaman lapangan) sehingga di wilayah ini hanya didominasi oleh jenis Acropora. Percabangan pada Acropora berfungsi meneruskan sebagian arus sehingga akan memperkecil resiko patah pada percabangan karang jenis ini (Bottjer, 1980, Luthfi et al., 2016). Berkebalikan dengan stasiun 3 dan 4, stasiun 1 dan 2 (TS 1 dan TS 2) didominasi oleh karang bercabang (CB), karang berbentuk daun (CF), dan karang massive (CM) (Tabel 1). Secara tata letak kedua stasiun ini berada di depan pelabuhan perikanan yang dengan kepadatan tinggi (300 kapal sandar/hari) atau dengan kata lain lokasi kedua stasiun sangat dekat dengan dengan sumber stressor (pencemar, kegiatan perikanan, limbah oli). Stressor yang lain adalah sedimen yang berasal langsung muara sungai tepat didepan ke dua station ini. Sediment menjadi masalah besar karena dapat mengurangi penetrasi cahaya matahari kedalam perairan dan akan mengganggu proses fotosintesis simbion karang. Riegl dan Branch (1995) memberikan keterangan bahwa perairan laut yang tertutupi sediment pada kisaran $100 \mathrm{mg} / \mathrm{cm}^{2}$ akan mengurangi cahaya yang masuk kedalam perairan hingga $75 \%$. Karang yang menyerupai daun (CF) yang mendominasi di stasiun 1 adalah Echinopora lamellosa, sedangkan karang massive yang ditemukan di stasiun 2 dan mendominasi disana adalah Porites lutea dan Porites lobata. Ketiga karang ini terkategorikan $\mathrm{K}$ dan $\mathrm{S}$ dikarenakan memiliki kemampuan menutupi dirinya dengan mucus yang akan mencegah sediment masuk kedalam polip mereka (Philipp dan Fabricius, 2003). Strategi survival jenis karang E. lamellosa adalah ketika sediment terkumpul pada bagian tengah koloninya, maka karang ini akan melakukan fragmentasi dan melakukan regenerasi secara aseksual, yakni membuat koloni baru dimana pertumbuhan dimulai dari bagian pinggir karang yang terbebas dari sedimentasi (Philipp dan Fabricius, 2003). Sedangkan bentuk morfologi karang massive Porites yang biasanya membulat akan mengurangi tumpukan sedimen dipermukaan koloninya dibandingkan dengan karang dengan foliose. 
Tabel 1. Life form karang yang ditemukan pada setiap lokasi penelitian

\begin{tabular}{|c|c|c|c|c|c|c|}
\hline \multirow{2}{*}{ No. } & \multirow{2}{*}{ Life form Karang } & \multicolumn{4}{|c|}{ Stasiun } & \multirow{2}{*}{ Jumlah } \\
\hline & & WM 1 & WM 2 & TS 1 & TS 2 & \\
\hline 1. & ACB & 36 & 135 & 36 & 11 & 218 \\
\hline 2. & ACT & 6 & 0 & 0 & 0 & 6 \\
\hline 3. & СB & 33 & 1 & 90 & 281 & 405 \\
\hline 4. & $\mathrm{CE}$ & 15 & 12 & 1 & 78 & 106 \\
\hline 5. & $\mathrm{CF}$ & 14 & 52 & 136 & 7 & 209 \\
\hline 6. & $\mathrm{CM}$ & 45 & 44 & 23 & 325 & 437 \\
\hline 7. & CMR & 0 & 1 & 5 & 1 & 7 \\
\hline 8. & CS & 51 & 0 & 34 & 5 & 90 \\
\hline 9. & CME & 37 & 0 & 1 & 0 & 38 \\
\hline Total: & & 237 & 245 & 326 & 708 & 1516 \\
\hline
\end{tabular}

Keterangan : WM: Watu Mejo; TS: Teluk Semut; ACB: Acropora branching; ACT: Acropora tabullate; CB: Coral branching; CE :Coral encrusting; CF: Coral foliose; CM: Coral massive; CMS: Coral mushroom; CS: Coral submassive; CME: Coral melliopora

Tabel 2. Tutupan Dasar Perairan Sendang Biru (\%)

\begin{tabular}{clcccc}
\hline \multirow{2}{*}{ No } & \multirow{2}{*}{ Jenis Tutupan } & \multicolumn{3}{c}{ Nama Stasiun } \\
\cline { 3 - 6 } & & TS 1 & TS 2 & WM 1 & WM 2 \\
\hline 1. & Life Coral & $\mathbf{4 2 . 4}$ & 6.94 & $\mathbf{3 9 . 2}$ & 8.08 \\
2. & Dead Coral & 46.3 & 78.58 & 55.86 & 80.76 \\
3. & Algae & 0 & 0.64 & 3.04 & 3.98 \\
4. & Abiotik & 11.3 & 13.84 & 1.9 & 5.22 \\
5. & OT* & 0 & 0 & 0 & 2.04 \\
\hline
\end{tabular}

Keterangan (*): OT (Other): Biota laut yang tidak termasuk dalam kategori perhitungan

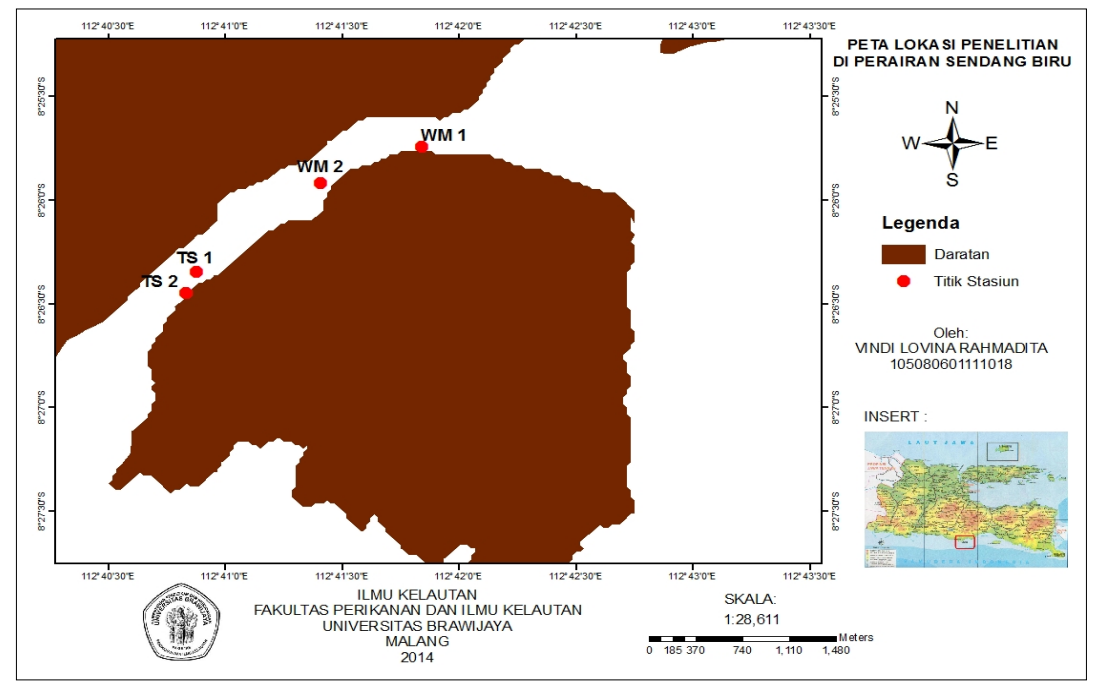

Gambar 1 Lokasi Penelitian di perairan P. Sempu, Malang 
Luthfi, O.M., Rahmadita, V.L., dan Setyohadi, D. (2018). Melihat Kondisi Kesetimbangan Ekologi Terumbu Karang di Pulau Sempu, Malang Menggunakan Pendekatan Luasan Koloni Karang Keras (Scleractinia). Jurnal IImu Lingkungan, 16(1), 1-8, doi:10.14710/jil.16.1.1-8

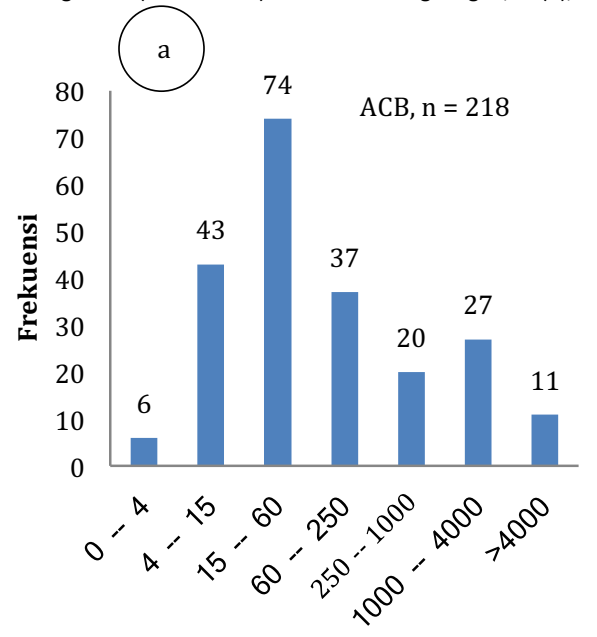

Ukuran Koloni $\left(\mathrm{cm}^{2}\right)$

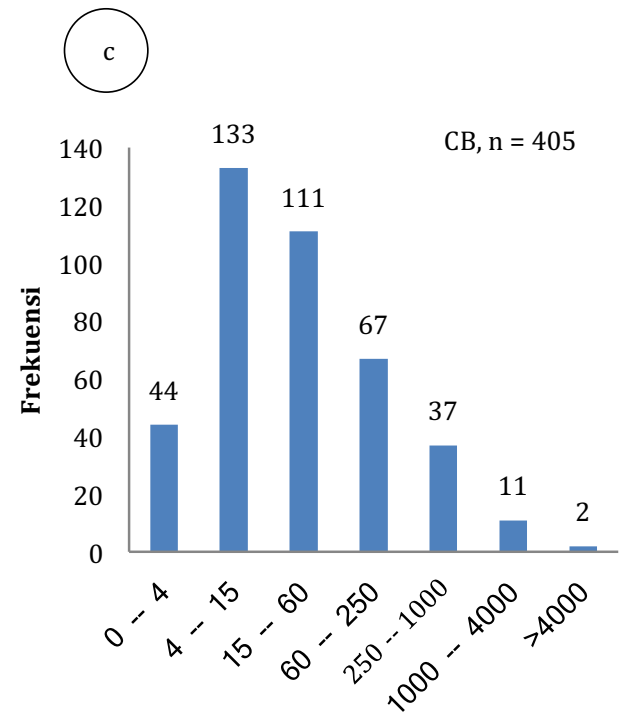

Ukuran Koloni $\left(\mathrm{cm}^{2}\right)$
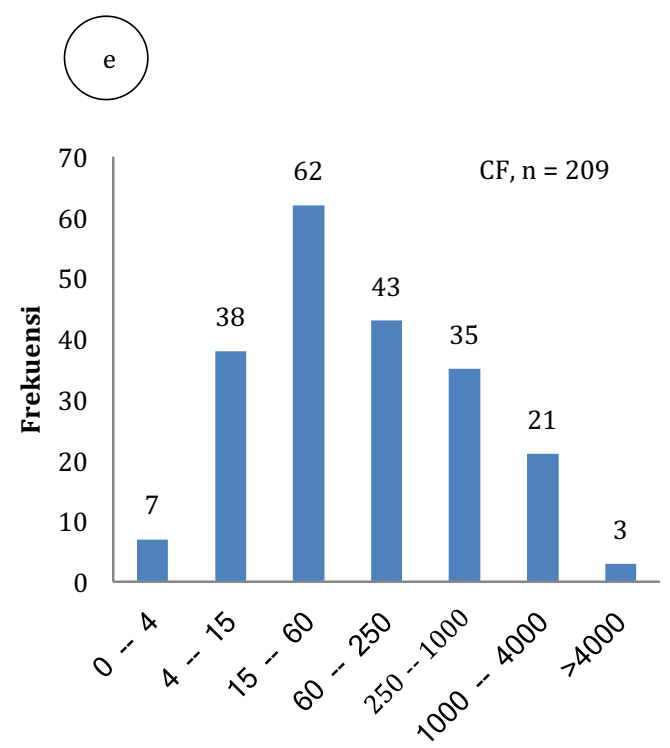

Ukuran Koloni ( $\left.\mathrm{cm}^{2}\right)$

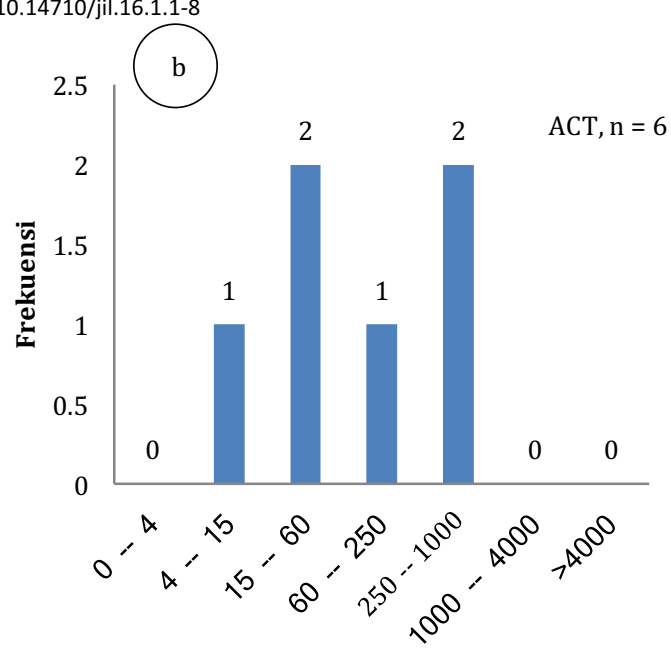

Ukuran Koloni (cm²)

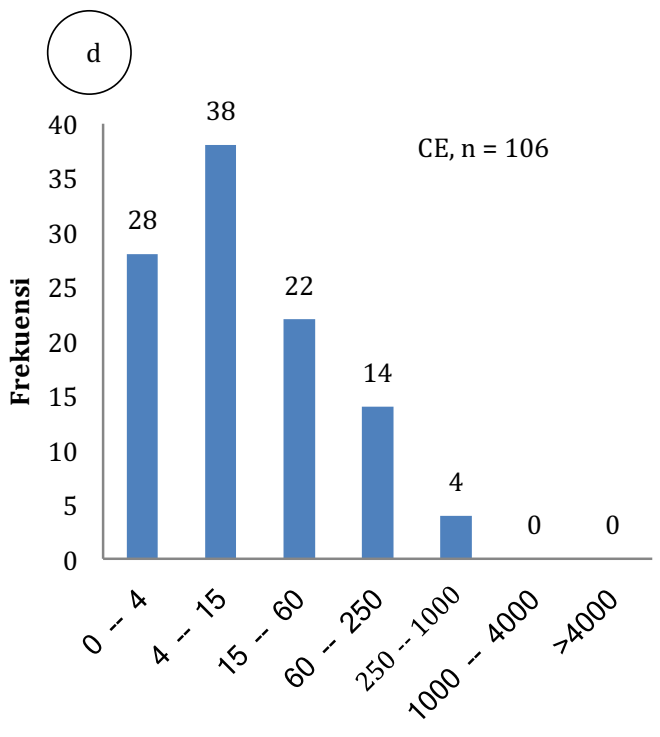

Ukuran Koloni ( $\left.\mathrm{cm}^{2}\right)$
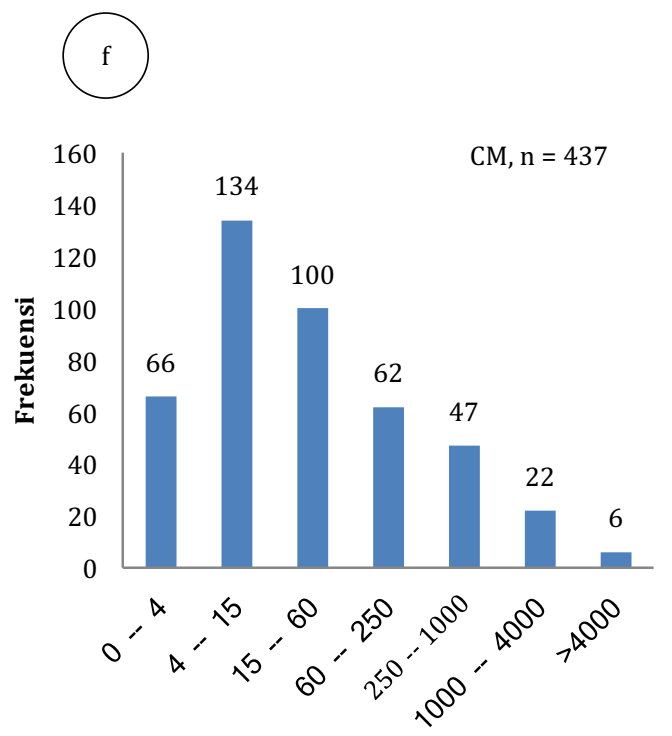

Ukuran Koloni ( $\left.\mathbf{c m}^{2}\right)$ 


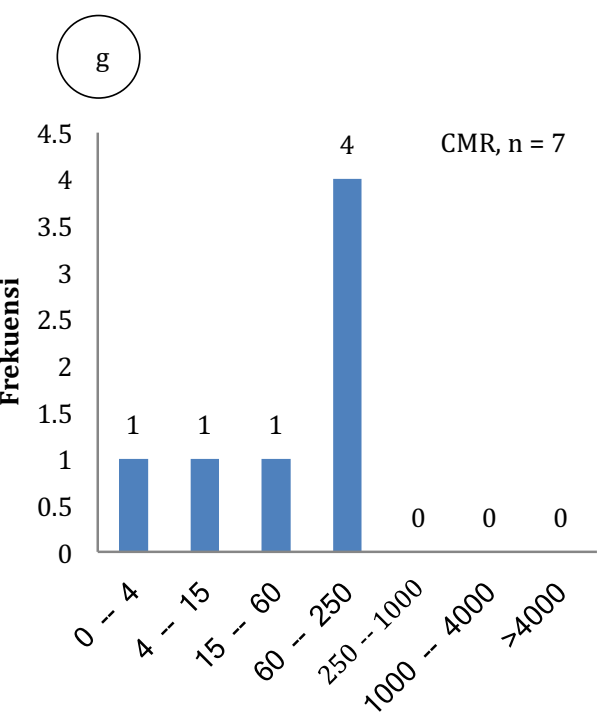

Ukuran Koloni $\left(\mathrm{cm}^{2}\right)$

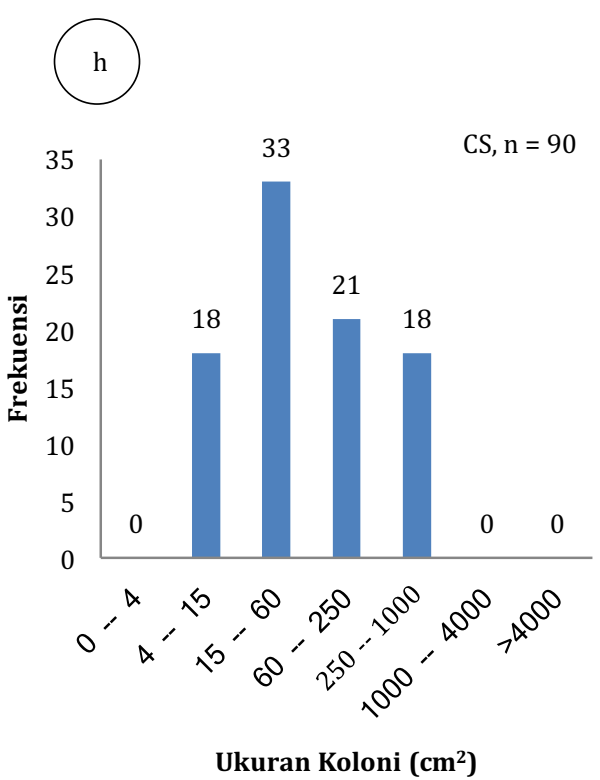

Ukuran Koloni $\left(\mathrm{cm}^{2}\right)$

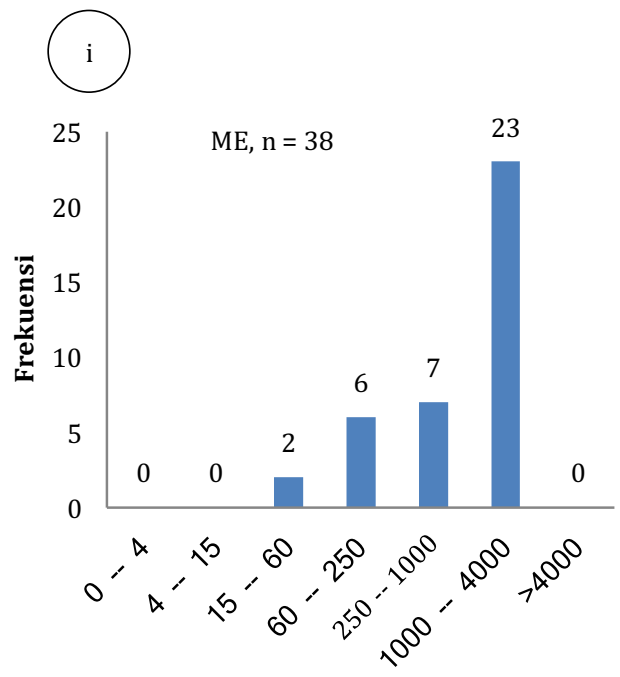

Ukuran Koloni $\left(\mathrm{cm}^{2}\right)$

Gambar 1. Distribusi ukuran karang keras yang ditemukan di P. Sempu, Malang. a-i menunjukkan bentuk pertumbuhan (life form) dari karang keras dimana ACB: Acropora Branching; ACT: Acropora Tabulate; CB: Coral Branching; CE: Coral Encrusting; CF: Coral Foliose; CM: Coral Massive; CMR: Coral Mushroom; CS: Coral Submassive dan ME: Millepora

\subsection{Persentase Tutupan Karang Hidup}

Tutupan karang hidup di P. Sempu berkisar pada angka 6,94-42,4\%, atau terklasifikasi dalam kondisi rusak hingga sedang (Tabel 2). Dan menunjukkan kebalikannya, karang mati (dead coral) pada WM2 memiliki prosentase yang sangat tinggi $(80,76 \%)$. Distribusi frekuensi karang keras berdasarkan bentuk pertumbuhannya ada yang memiliki rentang kecil (0$4 \mathrm{~cm}^{2}$ ) hingga $>4000 \mathrm{~cm}^{2}$ seperti pada bentuk pertumbuhan Acropora bercabang, karang bercabang, karang berbentuk daun dan karang massive (Gambar 2a, 2c, 2e, dan 2f). Secara umum bentuk grafik pada gambar 2 akan menyerupai genta dengan arah condong (skewness) kekiri.
Stressor lingkungan yang sangat beragam di statiun 3 ternyata tidak mengurangi persentase karang hidupnya, pada table 2 persent tutupan karang keras di stasiun ini adalah $42,4 \%$, juga demikian pada stasiun 1, tutupan karang hidup sekitar 39,2\% walaupun arus dilokasi ini cukup kencang. Persentase karang mati di P. Sempu cukup besar (Tabel 2) 55,86$80,76 \%$. Tingginya karang yang ditemukan di perairan P. Sempu diakibatkan oleh berbagai faktor yang tentunya berlangsung secara terus menerus. Dari pengamatan dilapangan ada beberapa stressor atau ancaman yang mempengaruhi pada tingginya kematian karang di pulau ini, seperti sedimentasi, kenaikan suhu air laut, polutan minyak, kegiatan 
wisata dan pencarian ikan dengan cara merusak. Dan ternyata faktor-faktor tadi sama dengan kawasan lain di Indonesia (Edinger et al, 1998). Terumbu karang yang terletak didekat pesisir memang memiliki potensi ancaman lebih besar bila dibandingkan didaerah kepulauan yang jauh dari daratan utama. Fabricius (2005) memberikan penjelasan dampak yang diakibatkan dari daratan utama terhadap keberadaan terumbu karang seperti: berkurangnya laju pembentukan kapur (kalsifikasi) yang akan berdampak kepada terhambatnya pertumbuhan karang, mengganggu system rerpoduksi dan pola recruitment karang, meningkatka jumlah competitor (alga dan sponge), meningkatnya penyakit pada karang, dan meningkatkan kematian karang. Berdasarkan data pada table 2 dapat digambarkan penurunan karang hidup yang diakibatkan dari tekanan dari lingkungan akan memperbesar persentasi kematian karang di P. Sempu dan kemungkinan meningkatkan jumlah kompetitior dari karang di perairan P. Sempu.

\subsection{Distribusi frekuensi}

Luasan koloni karang adalah paling cocok digunakan untuk mengestimasi persentase tutupan karang hidup pada suatu perairan, dimana penggambarannya akan sepadan dengan luasan transek yang telah dilakukan. Informasi lain yang didapatkan dari luasan koloni adalah dengan melihat distribusi frekuensi luasan koloni tersebut. Pada gambar 2 didapatkan berbagai variasi ukuran koloni karang yang secara simple akan di kategorikan sebagai juvenile $<100 \mathrm{~cm}^{2}$, puberty $>100 \mathrm{~cm}^{2}$ dan besar $>4000 \mathrm{~cm}^{2}$ (Soong, 1993). Meskipun secara teori proses reproduksi dan recruitment karang di P. Sempu terganggu akibat tekanan faktor lingkungan namun berdasarkan gambar 2 jumlah juvenile dan karang yang puberty mendominasi dibandingkan dengan jumlah karang yang berukuran besar. Berarti sebenarnya tekanan lingkungan tidak terjadi setiap saat di P. Sempu dan disaat yang lain kondisi lingkungan justru sangat mendukung terjadinya regenerasi karang. Seperti peran arus yang segera menyapu mucus karang yang sudah terkontaminasi oleh sediment sehingga karang tidak mengalami anoxia dan pemutihan local dipermukaan koloninya. Peran arus juga menditribusikan makanan alami karang yakni plankton dan juga mengatur suhu di air laut sehingga temperature di air laut selalu stabil (Shinn, 1976; Nonaka dan Xie, 2003). Jumlah karang yang berukuran besar di P. Sempu sangat sedikit, dimungkinkan karena diambil secara fisik untuk kebutuhan manusia atau rusak secara alami dikarenakan peran bioeroder. Setidaknya ada lebih 100 macam bioeroder yang tinggal pada karang massive, dan akan mempercepat proses fragmentasi karang menjadi koloni lebih kecil (Glynn dan Manzello, 2015).

\section{Kesimpulan}

Bentuk pertumbuhan karang keras di P. Sempu didominasi oleh coral massive, coral branching, coral foliose dan acropora branching. Karang di P. Sempu secara alamiah memiliki kesempatan untuk pulih atau menjadi lebih bagus apabila didukung oleh faktor lingkungan yang lebih baik dan pengurangan stressor.

\section{Ucapan Terima Kasih}

Kami mengucapkan banyak terima kasih kepada Kelompok Studi Terumbu Karang (Acropora) yang telah banyak membantu pengambilan data dilapangan. Penelitian ini didanai oleh DIPA Universitas Brawijaya Nomor: 007/Add/SP2H/PL/DIT.LITABMAS/V/2015.

\section{DAFTAR PUSTAKA}

Bak, R.P. and Meesters, E.H., 1998. Coral population structure: the hidden information of colony size-frequency distributions. Marine Ecology Progress Series, 162: 301-306.

Bottjer, D.J., 1980. Branching morphology of the reef coral Acropora cervicornis in different hydraulic regimes. Journal of Paleontology, 54(5): 1102-1107.

Bruno, J.F. and Selig, E.R., 2007. Regional decline of coral cover in the Indo-Pacific: timing, extent, and subregional comparisons. PLoS one, 2(8): 711.

Edinger, E.N. and Risk, M.J., 2000. Reef classification by coral morphology predicts coral reef conservation value. Biological Conservation, 92(1): 1-13.

Edinger, E.N., Jompa, J., Limmon, G.V., Widjatmoko, W. and Risk, M.J., 1998. Reef degradation and coral biodiversity in Indonesia: effects of land-based pollution, destructive fishing practices and changes over time. Marine Pollution Bulletin, 36(8): 617630.

English, S., C. Wilkinson, V. Baker. 1994. Survey Manual for Tropical Marine Resources. Australian Institute of Marine Science, Townsville.

Fabricius, K.E., 2005. Effects of terrestrial runoff on the ecology of corals and coral reefs: review and synthesis. Marine pollution bulletin, 50(2): 125-146

Glynn, P.W. and Manzello, D.P., 2015. Bioerosion and coral reef growth: a dynamic balance. In Coral Reefs in the Anthropocene (67-97). Springer Netherlands.

Hughes, T.P., 1989. Community structure and diversity of coral reefs: the role of history. Ecology, 70(1): 275-279.

Loya, Y. and Slobodkin, L.B., 1971. The coral reefs of Eilat (Gulf of Eilat, Red Sea). In Symp. Zool. Soc. Lond Vol. 28: 117-139.

Loya, Y., 1972. Community structure and species diversity of hermatypic corals at Eilat, Red Sea. Marine Biology, 13(2): 100-123.

Luthfi, O.M, A Isdianto, EJ Sari. 2016. Dominance of Acroporids Coral in Coral Reef of Bali Strait, Indonesia. Proc. Basic Sci., 6. Malang: 173-178.

Luthfi, O.M., Alfan Jauhari dan Guntur. 2014. Melihat status nilai konservasi terumbu karang dan ide pembuatan taman karang di Kawasan Lindung (Cagar Alam) Pulau Sempu, Malang Selatan. Proseding Seminar Internasional Conservation and Management of Marine Ecosystem. Universitas Brawijaya, Malang. 28 Maret 2014.

Luthfi, O.M., Nakamura, T. and Tsuchiyab, M. 2015. Coral Disease Assessment in Karimunjawa National Park, Central Java Indonesia. International Fisheries Symposium 2-4 Desember 2015, Penang Malaysia.

Luthfi, O.M., Pujarahayu, P., Wahyudiarto, A., Fakri, S.R., Sofyan, M., Ramadhan, F., Murian, S., Tovani, I., Mahmud, M., Adi, D. and Abdi, F., 2016. Reef Fish Biodiversity and Population in Sempu Strait Waters Sendang Biru Malang Regency East Java. Jurnal Kelautan: Indonesian Journal of Marine Science and Technology, 9(1): 43-49. 
Nonaka, M. and Xie, S.P., 2003. Covariations of sea surface temperature and wind over the kuroshio and its extension: evidence for ocean-to-atmosphere feedback. Journal of climate, 16(9): 1404-1413.

Pandolfi, J.M., Bradbury, R.H., Sala, E., Hughes, T.P., Bjorndal, K.A., Cooke, R.G., McArdle, D., McClenachan, L., Newman, M.J., Paredes, G. and Warner, R.R., 2003. Global trajectories of the long-term decline of coral reef ecosystems. Science, 301(5635): 955-958.

Philipp, E. and Fabricius, K., 2003. Photophysiological stress in scleractinian corals in response to short-term sedimentation. Journal of Experimental Marine Biology and Ecology, 287(1): 57-78.

Riegl, B. and Branch, G.M., 1995. Effects of sediment on the energy budgets of four scleractinian (Bourne 1900) and five alcyonacean (Lamouroux 1816) corals. Journal of Experimental Marine Biology and Ecology, 186(2): 259-275.

Shinn, E.A., 1976. Coral reef recovery in Florida and the Persian Gulf. Environmental Geology, 1(4): 241-254.

Soong, K., 1993. Colony size as a species character in massive reef corals. Coral reefs, 12(2): 77-83.

Stoddart, D.R., 1969. Ecology and morphology of recent coral reefs. Biological Reviews, 44(4): 433-498.

Williams, I.D., Polunin, N.V. and Hendrick, V.J., 2001. Limits to grazing by herbivorous fishes and the impact of low coral cover on macroalgal abundance on a coral reef in Belize. Marine Ecology Progress Series, 222: 187-196. 